\title{
Authors' reply: Deliberate self-harm in adolescents
}

Singapore Med J 2015; 56(9): 531 doi: 10.11622/smedj.2015142

Dear Sir,

We thank Dr Ong Say How ${ }^{(1)}$ for contributing further information about the services provided by REACH for young people with mental health problems.

Yours sincerely,

Michelle $\underline{\text { Lauw}}^{1}$, Choon How $\underline{\text { How }}^{2}$, Cheryl $\underline{\text { Loh }}^{1}$

${ }^{1}$ Department of Psychological Medicine, ${ }^{2}$ Care and Health Integration, Changi General Hospital, Singapore. cheryl_loh@cgh.com.sg 